\title{
The learning effect on organizational performance during a crisis: a serial mediation analysis with knowledge creation, storage and sharing
}

\author{
Usman Ahmad Qadri \\ Universiti Sultan Zainal Abidin, Kuala Terengganu, Malaysia and \\ Institute of Southern Punjab, Multan, Pakistan \\ Mazuri Binti abd Ghani \\ Universiti Sultan Zainal Abidin, Kuala Terengganu, Malaysia \\ Shumaila Bibi \\ International Islamic University, Islamabad, Pakistan, and \\ Abdul Haseeb Tahir, Muhammad Imran Farooq and \\ Abdul Rauf Kashif \\ Institute of Southern Punjab, Multan, Pakistan
}

\begin{abstract}
Purpose - The aim of this study is to investigate the serially mediating effect of knowledge management (KM) practices (namely, knowledge creation, storage and sharing) on the organizational learning (OL) and organizational performance $(\mathrm{OP})$ relationships during a crisis.

Design/methodology/approach - Based on theories-of-action, knowledge-based and resource-based theories, this study proposed a sequential mediation model where OL underlying mechanisms through which $\mathrm{KM}$ practices have facilitated OP during the crisis. The sample dataset contains 440 responses collected from the managers of the software development companies in Pakistan. The authors used Hayes Process macro with SPSS to test the study hypotheses.

Findings - The results of the study reveal that knowledge creation, storage and sharing serially mediate the relationships between $\mathrm{OL}$ and $\mathrm{OP}$. These findings strengthen the argument suggesting that $\mathrm{OL}$ plays the key role in KM that helps software companies to mend their performance in times of crisis.

Originality/value - This study contributes to the KM literature in two ways: (1) grounded on the study's proposed framework, organizations can improve and manage their businesses in times of crisis and (2) learn how to generate new knowledge in response to business crises.
\end{abstract}

Keywords Organizational learning, Knowledge management practices, Organizational performance,

Theories of action, Covid-19 crisis, Software development industry

Paper type Research paper

\section{Introduction}

Learning during a crisis (i.e. Covid-19) is a very difficult and challenging task for a firm. A crisis is usually a kind of event for organizations that cannot be planned (Deverell, 2009; Alles, 2021).

(C) Usman Ahmad Qadri, Mazuri Binti abd Ghani, Shumaila Bibi, Abdul Haseeb Tahir, Muhammad Imran Farooq and Abdul Rauf Kashif. Published in European Journal of Management and Business Economics. Published by Emerald Publishing Limited. This article is published under the Creative Commons Attribution (CC BY 4.0) licence. Anyone may reproduce, distribute, translate and create derivative works of this article (for both commercial and non-commercial purposes), subject to full attribution to the original publication and authors. The full terms of this licence may be seen at http:// creativecommons.org/licences/by/4.0/legalcode

Knowledge management practices

Received 31 March 2021

Revised 16 July 2021

18 September 2021 Accepted 19 October 2021 
Although the harmful impact of the crisis on organizations has been studied extensively (Olsson, 2014), limited research has examined how companies can deal with these challenges and learn from a crisis, particularly in the software development industry (Boehm et al., 2020). An organization that actively compacts in an uncertain environment should not only create information and knowledge but also process it well. Similarly, successful organizations are those that adapt to changing environments and thrive despite external factors. Accordingly, software development companies are constantly looking for methods to improve quality and productivity (Gopalkrishna et al., 2012; Nguyen-Duc et al., 2015). Knowledge management (KM) processes, such as knowledge creation, storage and sharing, provide a platform for solving problems efficiently. In addition, many researchers have tried to explain how to develop and implement effective crisis management strategies to improve organizational performance (OP) in times of crisis (e.g. Carroll and Hatakenaka, 2001). Despite the growing interest in KM and $\mathrm{OP}$, insufficient attention has been paid to investigating the role of KM practices (i.e., knowledge creation, storage and sharing) in achieving OP, particularly with the aids of organizational learning (OL). In particular, more empirical studies are needed at the company level to determine what factors could interfere with OP during a crisis. With these lines, while handling crises (e.g. Covid-19), organizations need to process and apply a large amount of new data in a timely manner. They need to develop processes that enable them to achieve their goals effectively (Hu et al., 2021). Accordingly, the study of knowledge creation (KC) and OL is "pursued as independent themes in research [...] and the links between them tend to be forgotten [...] because it is hard to reconcile fundamental assumptions about knowledge, information, environment and learning" (Lyles, 2014, pp. 132-133).

In light of above arguments, this research addresses OL, which has been stated and suggested as a set of organizational values and norms. These days, firms are considered successful if they have the ability to learn and do it quickly. Consequently, this paper adds to extant research by investigating the sequential mediation relationship between OL and OP via knowledge creation, storage and sharing in the software development industry of Pakistan.

\section{Literature review and hypothesis development \\ 2.1 Theories}

Little is known about how knowledge is encoded in the employees' minds. According to Argyris et al. (1985), people create their own "mental maps," the way they act in a particular situation. These include how they plan, execute and review their behaviors. In OL, these mental maps guide the employees' actions rather than their theoretical claims (Argyris et al., 1985; Argyris, 2000). Although very few employees are familiar with the theories or maps they use; theories of action guide them to consider changes in the depth of knowledge. Theories of action are a "mechanism" through which employees associate their thoughts with their actions (Argyris et al., 1985). Argyris and Schon (1974) divided theories of action into two parts that govern employees' actions that affect OL. Accordingly, "espoused theories are those that an individual claims to follow; theories-in-use are those than can be inferred from action" (Argyris et al., 1985, p. 82). In this study, the authors explain that OL's theories focus on $\mathrm{KC}$ and the use of that knowledge within the organization.

In addition, this study used theories such as knowledge-based view (KBV) and resourcebased view (RBV) to describe the KM processes and organizational performance of software companies. The RBV suggests that organizations can improve their performance and use their resources and capabilities to create a competitive advantage (Singh et al., 2019).

\subsection{KM practices}

Darroch (2005, p. 211) defines KM as a "management function that creates or locates knowledge, manages the flow of knowledge within organizations and ensures that the 
knowledge is used effectively and efficiently for the long-term benefit of the organization." This study uses $3 \mathrm{KM}$ dimensions (namely, knowledge creation, storage and sharing). However, KM varies from study to study. For example, according to Ode and Ayavoo (2020), KM practices are based on knowledge application and use. Early studies of KM such as Addis (2016), focused on the KC process and knowledge transfer with an emphasis on implicit and explicit knowledge. While recent studies identify "knowledge creation, acquisition, sharing and application" as the main components of the KM processes (Ode and Ayavoo, 2020), others have identified the knowledge creation, transfer, storage and application as the key KM processes (Al-Emran et al., 2018). The importance of KM for software development companies is incredible. KM helps improve implementation and coordination across the company, which is a challenge for software companies. Furthermore, KM also helps in delivery speed and execution accuracy for software companies (Khosravi and Nilashi, 2018).

\subsection{Hypothesis development}

2.3.1 Direct relationship between OL, KM processes and OP. In the times of Covid-19 crisis, the process of learning and KM within organizations is being given much importance (Velásquez and Lara, 2021). Despite a lot being written about OL, little attention is being paid to KM, which is a big issue. Prior to that, most of OL's theories were based on the misconception that "the development of knowledge shapes learning" (Senge, 1990). Later, Nonaka and Takeuchi (1995) expose the fallacy of the idea and state that "a comprehensive view of what constitutes OL has not been developed." According to Mehralian et al. (2018), OL has the potential to enhance the efficiency of the learning process and $\mathrm{KC}$ in software companies. In other words, there are learning process requirements to enhance the quality of software products (Saha and Annamalai, 2021). Similarly, learning through better information and understanding has led to a change in behavior that helps improve organizational performance (Ullah et al., 2021). In addition, OL is important to the organization's customers because it involves meeting and understanding latent needs through new services, products and ways of doing business (Zhang et al., 2020). Concurrently, OL has proven to be invaluable in improving performance within software companies (Waheed et al., 2019). Therefore, organizations should use OL to generate new knowledge (Pasamar et al., 2019). In addition, several prior studies have suggested significant and positive relationships between OL, KM and OP, as shown in Table 1.

Accordingly, companies with technology capabilities and high-level $\mathrm{KC}$ are more efficient and can improve organizations (Abusweilem and Abualoush, 2019). Therefore, knowledge is a key success factor in obtaining competitive advantage in the times of crisis (Mehralian et al., 2018). According to Abusweilem and Abualoush (2019), KM processes (i.e. KC, knowledge storage [KS] and knowledge sharing [KSI]) that enhance intermediate $\mathrm{OP}$ will lead to positive financial performance. Consequently, in the essence of RBV theory, we propose that if a company obtains resources and uses them effectively, it may have a major "strategic advantage" that will increase OP. Thus, we suggested that

H1. (a) OL, (b) KC, (c) KS and (d) KSI are effective in improving OP.

In addition, Boella et al. (2016) stated that the organization's success is highly dependent on knowledge and KM. From the KM processes, KSI is valuable for organizations as it helps them improve performance (Obeidat and Zyod, 2015). In addition, it is important for organizations to exchange knowledge as it promotes OL (Park and Kim, 2018). In other words, Park and Kim (2018) proposed the positive relationship between OL and KSI. Accordingly, one of the important outcomes of KM is KC (Argote et al., 2003). The value of the KC depends on level of KSI and skills among people across the organization (Oliveira et al., 2020). Subsequently, KC and KS are two vital aspects of KM that play an important role in creating

\section{Knowledge management practices}




EJMBE

Table 1.

Critical synthesis literature review on $\mathrm{OL}$, $\mathrm{KM}$ and OP 


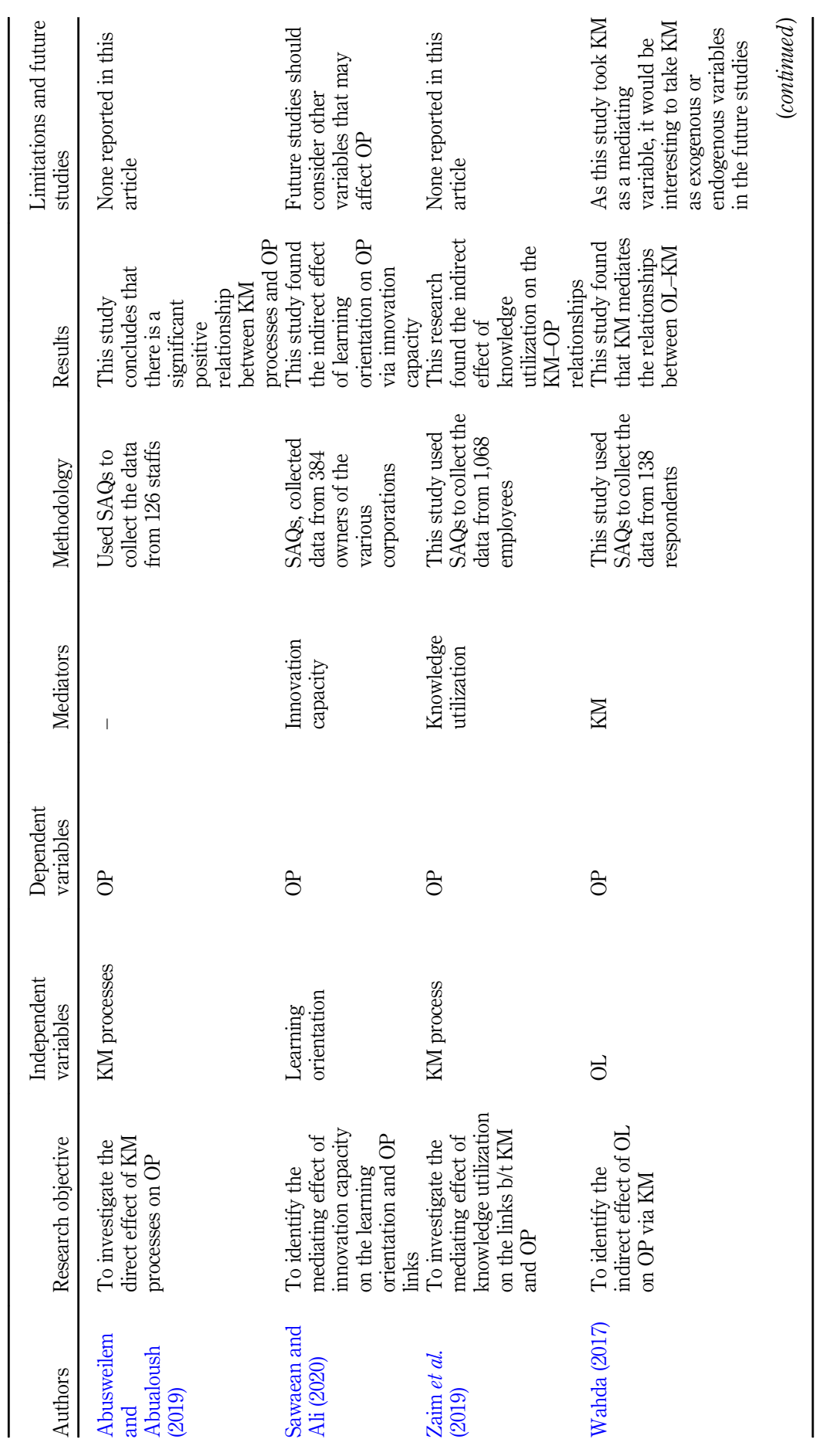

Knowledge management practices

Table 1. 
EJMBE

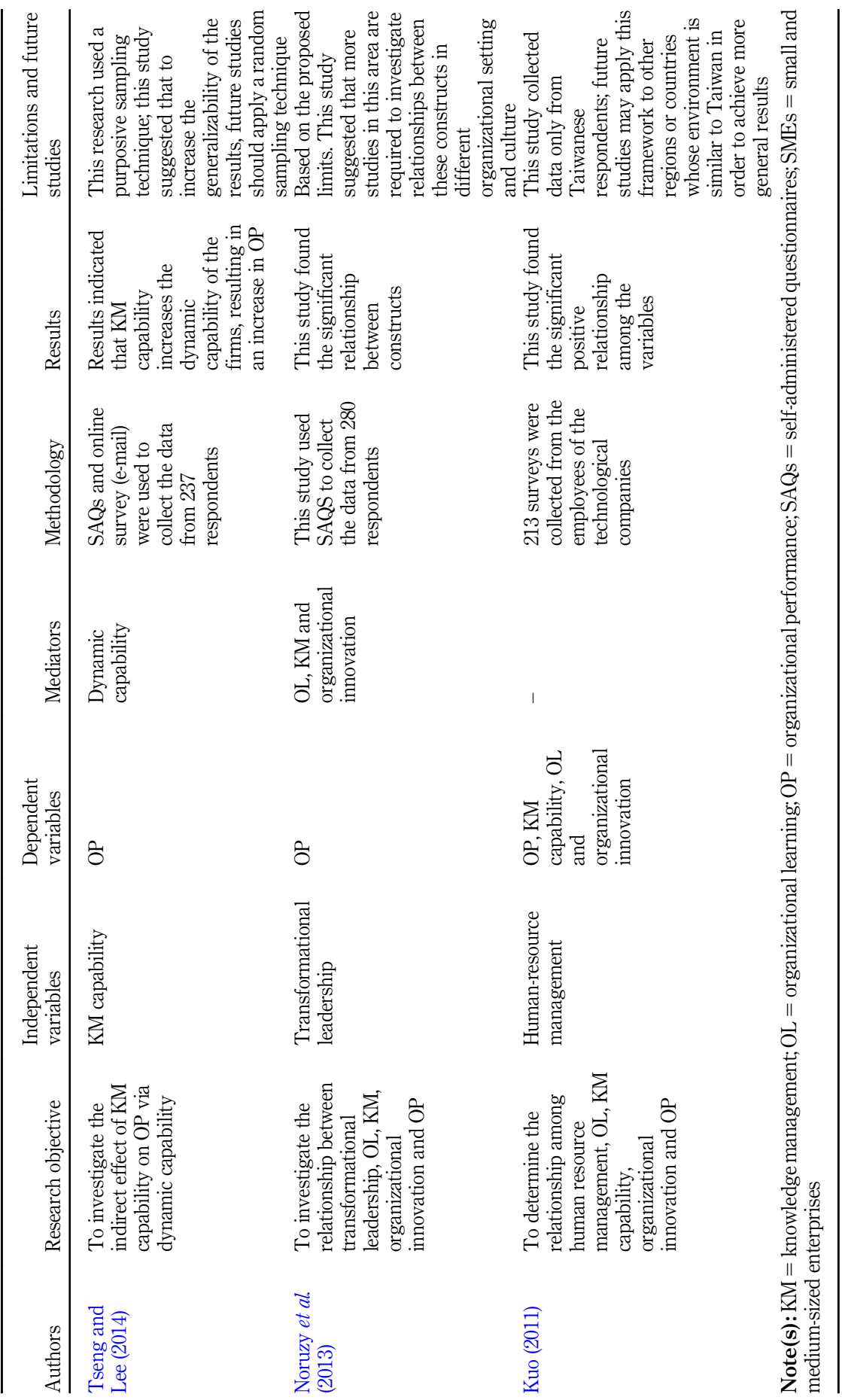

Table 1. 
organizational value. In KM, KS is a phase to store explicit knowledge. Therefore, most organizations in the software development industry are focused on improving their KSI capability to create new knowledge (Carmeli et al., 2013). This also helps to retrieve knowledge for later usages as well. So, we proposed that

\section{H2. (a) OL, (b) KC and (c) KS are effective in improving KSI activities.}

2.3.2 Serial mediation effect of KC, KS and KSI. A number of studies (Calabretta et al., 2017) have examined how KC plays a key role in the success and survival of a firm. In addition, Calabretta et al. (2017, p. 392) subsumes the KC process "embedding new ideas, cognitive frames, and manners of thinking in organizations require adaptation (i.e., translation) to the specific practices and socio-cultural context of the target organization." Accordingly, companies can enhance both financial and nonfinancial performance through affected $\mathrm{KC}$ methods (Kao and $\mathrm{Wu}, 2016$ ). Previous research (Sahibzada et al., 2020) proposed the direct relationships between KC, KS and KSI. Contrariwise, none of these studies identified an indirect relationship between them. In addition, Zaim et al. (2019), investigate the significant positive association between KM practices and OP. Accordingly, learning has the significant positive effect on KC and KS (Abusweilem and Abualoush, 2019), which in turn lead to increase organizational OP (Kordab et al., 2020). Thus, the following hypotheses are proposed:

H3. (a) KC, (b) KS and (c) KSI mediate the relationship between $\mathrm{OL}$ and $\mathrm{OP}$.

H4. (a) KC and KS, (b) KC and KSI, (c) KS and KSI, and (d) KC, KS and KSI serially mediate the relationship between $\mathrm{OL}$ and $\mathrm{OP}$.

\section{Research design}

\subsection{Research model and measurement}

Based on theory of action, KBV and RBV theories, we proposed that the three mediators - KC, $\mathrm{KS}$ and KSI could play the role of sequential mediator between OL and OP. This means that $\mathrm{OL}$ affects $\mathrm{OP}$ via KC, KS and KSI in a sequential manner (see, Figure 1). Grounded on theoretical framework, the study's questionnaire was prepared, and four items of OL were measured on a five-point Likert-scale ranging from " $1=$ strongly disagree to $5=$ strongly agree" adapted from the study of García-Morales et al., (2008). Furthermore, this study measured the three processes of KM (namely, knowledge creation, storage and sharing)

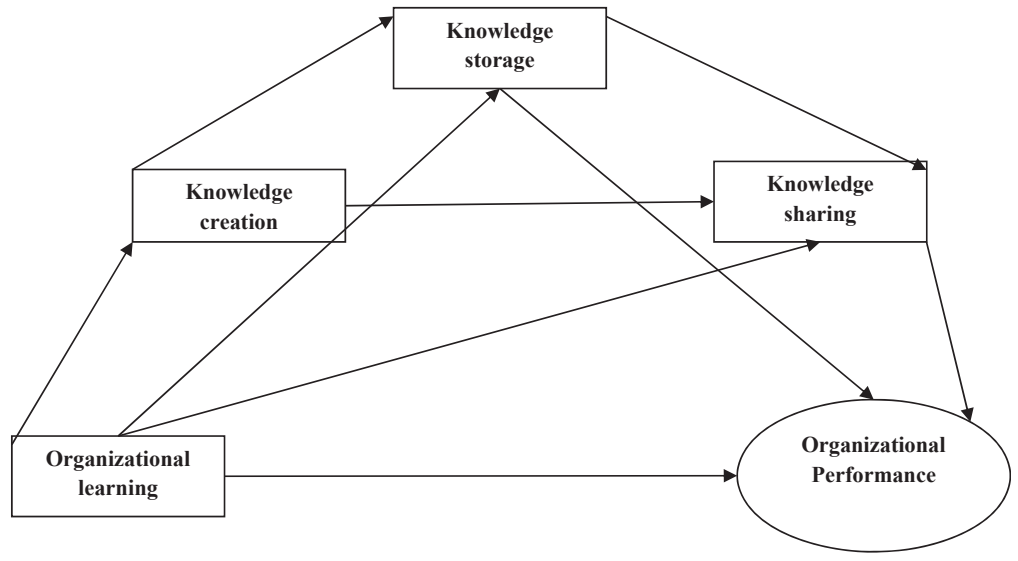

Figure 1. Research model 
through 14 items. In which, five items of $\mathrm{KC}$ and six items of KSI were measured through fivepoint Likert scale adapted from the study of Lee and Wong, (2015) and Holtshouse, (1998). While three items of KS were measured through five-point Likert-scale taken from the study of Hansen et al. (1999), four items of OP adapted from the study Cho et al. (2008) were measured through five-point scale from 1 (poor) to 5 (excellent) (see Appendix).

\subsection{Data collection and sampling}

During the second wave of the Covid-19 crisis, we used a self-report cross-sectional survey method to collect the data from the employees of software companies. Through which, we selected 20 companies randomly in the software development industry in Lahore, Multan and Islamabad, which had more than 20 workers. In 20 companies, 17 allowed their employees to participate in the survey. The study survey was written in English because it is the official language of business and higher education in Pakistan. Furthermore, recent research (e.g. Fatima et al., 2020; Qadri et al., 2020) conducted in Pakistan and published in mainstream journals has demonstrated that the survey format is feasible. Consequently, each study questionnaire was accompanied by a cover letter, which explained the purpose of the study and the volunteer nature of the respondents. Therefore, considering our sample, we did not translate the survey into Urdu. After completing the survey format, we met with lower-, middle- and top-level managers of software companies and asked them to participate in the survey.

In addition, this study used purposive sampling techniques as a data collection strategy because it is less expensive and usually requires less time (Etikan et al., 2016). We collected the data between October 2020 and November 2020. The data compilation process lasted for four working weeks. Since our research model had five variables and a total of 22 items, the minimum size of the sample required for our study was $110(22 \times 5=110)$. The size of the sample used in our study (i.e. $N=440$ ) is larger than the required sample size and therefore adequate enough for analysis and give more reliable results with greater precision and power (Benner and Waldfogel, 2008).

Consequently, we distributed 610 questionnaires; among them, in which 440 were returned, we selected 425; the rate of response was $72.13 \%$. In the study, we removed 15 surveys that had incomplete answers. Of the respondents, $43 \%$ were females. All sampling employees had an average of five years with the company. Of the respondents, $40 \%$ belonging to the company have more than 100 employees. The majority of respondents $(55 \%)$ was lower/first line managers in their companies.

\section{Data analysis and finding \\ 4.1 Control variables}

This study statistically controlled the effect of gender $(1=$ Male, $2=$ Female), age $(1=20-35$, $2=36-50,3=51-65,4=65+$ ), tenure (in years) in the software development company and designation (" 1 = first-line manager, 2 = middle manager, 3 = top manager"), we made sure they would not affect other variables of interest.

\subsection{Reliability and correlation analysis}

The mean, standard deviation, correlation coefficient and discriminant validity values of the study constructs are in Table 2 . We have found a positive significant correlation between KSI and KS at $(r=0.365, p<0.001)$, OL and KS at $(r=0.379, p<0.001)$, OL and KSI at $(r=0.678$, $p<0.001)$, KC and KS at $(r=0.357, p<0.001)$, KC and KSI at $(r=0.464, p<0.001)$, and KC and $\mathrm{OL}$ at $(r=0.633, p<0.001)$. In addition, this study uses "Cronbach's alpha" to assess the scales internal reliability. In this study, Table 3 shows that alpha values of OL is 0.868 for four 


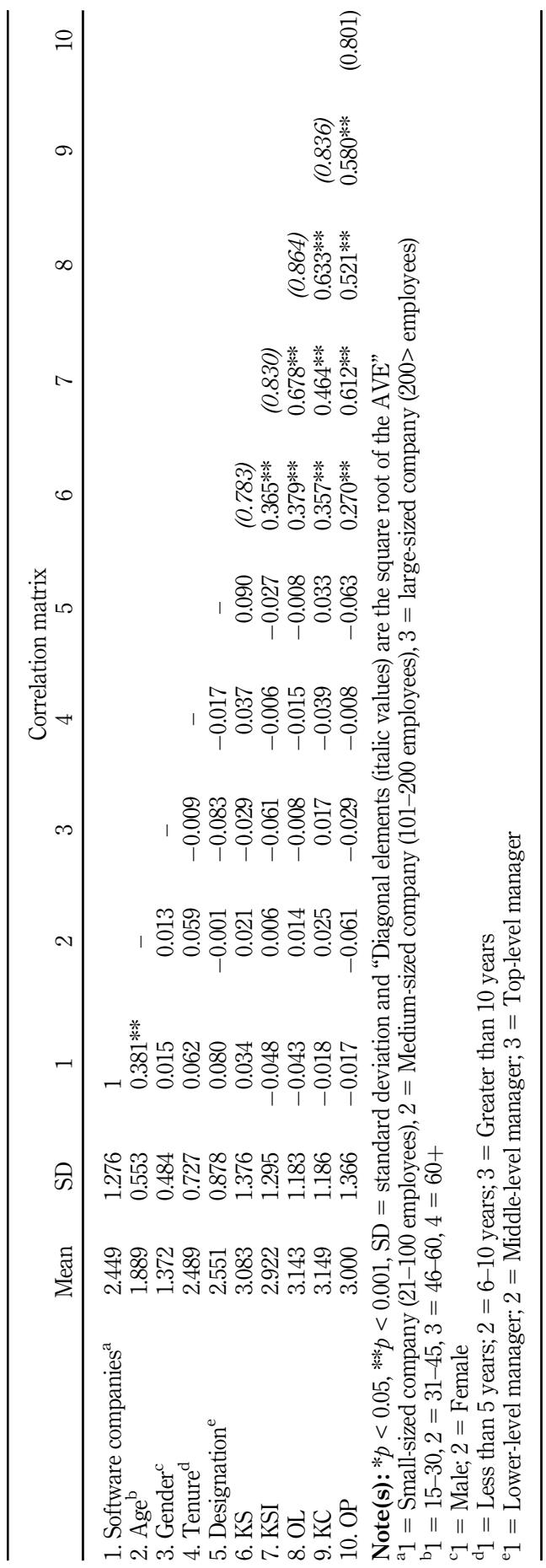

Knowledge management practices

Table 2. Means, standard deviations, correlations and validity 


\section{EJMBE}

Table 3.

Measurement model reliability and validity

\begin{tabular}{|c|c|c|c|c|c|c|c|}
\hline Constructs & Scale & $\begin{array}{l}\text { Factor loadings } \\
(\lambda)\end{array}$ & Alpha & $\begin{array}{c}\operatorname{MaxR} \\
(H)\end{array}$ & CR & AVE & MSV \\
\hline Organizational learning (OL) & $\begin{array}{l}\text { OL1 } \\
\text { OL2 } \\
\text { OL3 } \\
\text { OL4 }\end{array}$ & $\begin{array}{l}0.685 \\
0.859 \\
0.866 \\
0.779\end{array}$ & 0.868 & 0.981 & 0.876 & 0.641 & 0.531 \\
\hline Knowledge creation $(\mathrm{KC})$ & $\begin{array}{l}\text { KC1 } \\
\text { KC2 } \\
\text { KC3 } \\
\text { KC4 } \\
\text { KC5 }\end{array}$ & $\begin{array}{l}0.725 \\
0.766 \\
0.842 \\
0.755 \\
0.821\end{array}$ & 0.881 & 0.893 & 0.887 & 0.613 & 0.494 \\
\hline Knowledge storage (KS) & $\begin{array}{l}\text { KS1 } \\
\text { KS2 } \\
\text { KS3 }\end{array}$ & $\begin{array}{l}0.837 \\
0.819 \\
0.499^{\mathrm{a}}\end{array}$ & 0.813 & 0.930 & 0.816 & 0.690 & 0.206 \\
\hline Knowledge sharing (KSI) & $\begin{array}{l}\text { KSI1 } \\
\text { KSI2 } \\
\text { KSI3 } \\
\text { KSI4 } \\
\text { KSI5 } \\
\text { KSI6 }\end{array}$ & $\begin{array}{l}0.809 \\
0.759 \\
0.818 \\
0.860 \\
0.877 \\
0.887\end{array}$ & 0.942 & 0.977 & 0.933 & 0.6990 & 0.531 \\
\hline $\begin{array}{l}\text { Organizational performance } \\
\text { (OP) }\end{array}$ & $\begin{array}{l}\text { OP1 } \\
\text { OP2 } \\
\text { OP3 } \\
\text { OP4 }\end{array}$ & $\begin{array}{l}0.722 \\
0.920 \\
0.897 \\
0.900\end{array}$ & 0.900 & 0.966 & 0.921 & 0.746 & 0.445 \\
\hline
\end{tabular}

Note(s): ${ }^{a}$ Deleted, $\mathrm{CR}=$ Composite reliability; $\operatorname{MaxR}(\mathrm{H})=$ Maximum reliability; $\mathrm{MSV}=$ Maximum shared variance; $\mathrm{AVE}=$ Average variance extracted; $\lambda=$ Standardized regression weights

items, $\mathrm{KC}$ is 0.881 for five items, $\mathrm{KS}$ is 0.813 for two items, KSI is 0.913 for six items and alpha of OP is 0.900 for four items, which is higher than the threshold, as suggested by Nunnally (1978).

\subsection{Confirmatory factor analysis (CFA)}

In this study, we run confirmatory factor analysis (CFA) through AMOS version 24 to validate the element structure of a set of observed variables and to ensure that what extent our model fits the data. Table 3 shows that regression weights " $\lambda$ " of all items range from 0.685 to 0.920 , which are in the acceptable range, as suggested by Truong and McColl (2011). In addition, Table 3 shows that AVE $>0.50$, and CR $>0.60$ for all the variables; this means there is no "convergent validity" issue in the research. Further, AVE square root was greater than its corresponding correlation elements, as shown in Table 3. These findings show that the CFA model meets the criteria for measuring discriminant and convergent validity. This study assessed the measurement model fit by measuring the CCMIN/DF, GFI, RMSEA, AGFI, CFI and NNFI (TLI). The results indicated that all fit indices met the required criteria for determining the goodness fit of the measurement model, as shown in Table 4.

\subsection{Hypothesis testing}

To test the research hypotheses, this study used Model 6 of the process macro in SPSS version 24, as suggested by Hayes (2013). Table 5 shows the standardized estimate and standard error with lower and upper bounds of the "confidence interval" derived from bootstrap 5,000 resamples. As shown in Table $5, R^{2}$ is $(0.4003)$ which explained $40.03 \%$ of the variance of $\mathrm{KC}$, $R^{2}$ is (0.1664) that explained the $16.64 \%$ of the variance of KS, $(0.4735) 47.35 \%$ of the variance of KSI and $R^{2}$ is (0.4869) that described the $48.69 \%$ of the variance of OP. In addition, Table 2 


\begin{tabular}{|c|c|c|c|c|c|}
\hline Fit indices & Abbr & $\begin{array}{l}\text { Recommended } \\
\text { values }\end{array}$ & Scores & Sources & $\begin{array}{l}\text { Knowledge } \\
\text { management }\end{array}$ \\
\hline $\begin{array}{l}\text { Chi-square/Degrees of freedom } \\
\text { (CMIN/DF) }\end{array}$ & $\chi^{2} / \mathrm{df}$ & $\leq 3.00$ & $2.516^{\mathrm{a}}$ & Gefen (2000) & practices \\
\hline Tucker-Lewis index & TLI & $\geq 0.90$ & $0.954^{\mathrm{a}}$ & Bentler (1980) & \\
\hline Adjusted goodness-of-fit index & AGFI & $\geq 0.80$ & $0.886^{\mathrm{a}}$ & $\begin{array}{l}\text { Joreskog and Sorbom } \\
\text { (1993) }\end{array}$ & \\
\hline Goodness-of-fit index & GFI & $\geq 0.80$ & $0.919^{\mathrm{a}}$ & $\mathrm{Hu}(1998)$ & \\
\hline $\begin{array}{l}\text { Root mean square error of } \\
\text { approximation }\end{array}$ & RMSEA & $\leq 0.08$ & $0.060^{\mathrm{a}}$ & $\begin{array}{l}\text { Joreskog and Sorbom } \\
\text { (1993) }\end{array}$ & \\
\hline 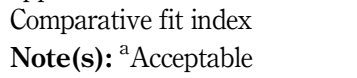 & CFI & $\geq 0.90$ & $0.964^{\mathrm{a}}$ & Bagozzi (1998) & $\begin{array}{l}\text { Fit indices of the } \\
\text { CFA model }\end{array}$ \\
\hline
\end{tabular}

$\mathrm{BC} 95 \% \mathrm{CI}$

Direct/Indirect/Total effect $\quad$ Estimate $\quad$ Standard error (SE) Upper bounds (BC) Upper bounds (BC)

\begin{tabular}{|c|c|c|c|c|}
\hline $\begin{array}{l}\text { Indirect effect } \\
\mathrm{OL} \rightarrow \mathrm{KC} \rightarrow \mathrm{OP}\end{array}$ & 0.251 & 0.040 & 0.461 & 0.650 \\
\hline $\mathrm{OL} \rightarrow \mathrm{KC} \rightarrow \mathrm{KS} \rightarrow \mathrm{OP}$ & -0.003 & 0.005 & -0.014 & 0.006 \\
\hline $\mathrm{OL} \rightarrow \mathrm{KC} \rightarrow \mathrm{KSI} \rightarrow \mathrm{OP}$ & 0.010 & 0.013 & -0.013 & 0.038 \\
\hline $\mathrm{OL} \rightarrow \mathrm{KC} \rightarrow \mathrm{KS} \rightarrow \mathrm{KSI} \rightarrow \mathrm{OP}$ & 0.007 & 0.003 & 0.002 & 0.015 \\
\hline $\mathrm{OL} \rightarrow \mathrm{KS} \rightarrow \mathrm{OP}$ & -0.007 & 0.010 & -0.030 & 0.011 \\
\hline $\mathrm{OL} \rightarrow \mathrm{KS} \rightarrow \mathrm{KSI} \rightarrow \mathrm{OP}$ & -0.012 & 0.005 & -0.004 & 0.025 \\
\hline $\mathrm{OL} \rightarrow \mathrm{KSI} \rightarrow \mathrm{OP}$ & 0.236 & 0.032 & 0.172 & 0.299 \\
\hline Direct effect & & & & \\
\hline $\mathrm{OL} \rightarrow \mathrm{KC}$ & 0.634 & 0.038 & 0.560 & 0.708 \\
\hline $\mathrm{KC} \rightarrow \mathrm{KS}$ & 0.226 & 0.066 & 0.096 & 0.357 \\
\hline $\mathrm{OL} \rightarrow \mathrm{KS}$ & 0.297 & 0.067 & 0.166 & 0.428 \\
\hline $\mathrm{KC} \rightarrow \mathrm{KSI}$ & 0.038 & 0.051 & -0.061 & 0.138 \\
\hline $\mathrm{KS} \rightarrow \mathrm{KSI}$ & 0.115 & 0.037 & 0.043 & 0.186 \\
\hline $\mathrm{OL} \rightarrow \mathrm{KSI}$ & 0.667 & 0.051 & 0.566 & 0.768 \\
\hline $\mathrm{KC} \rightarrow \mathrm{OP}$ & 0.456 & 0.053 & 0.352 & 0.560 \\
\hline $\mathrm{KS} \rightarrow \mathrm{OP}$ & -0.027 & 0.038 & -0.102 & 0.049 \\
\hline $\mathrm{KSI} \rightarrow \mathrm{OP}$ & 0.483 & 0.051 & 0.383 & 0.583 \\
\hline $\mathrm{OL} \rightarrow \mathrm{OP}$ & -0.035 & 0.063 & -0.159 & 0.090 \\
\hline Total effect of $\mathrm{OL} \rightarrow \mathrm{OP}$ & 0.601 & 0.048 & 0.507 & 0.695 \\
\hline
\end{tabular}

$R$-square

$\mathrm{KC}$

KS

KSI

OP

Table 5.

Direct, indirect and total effects of OL on $\mathrm{OP}$

shows that age and gender, tenure, the software companies and designation were not significantly correlated with the outcomes and predictor variables, therefore not included in the models as covariates.

4.4.1 Direct effect. In Table 5, OL has a positive effect on $\mathrm{KC}$ at $(\beta=0.634, \mathrm{SE}=0.038 ; 95 \%$ $\mathrm{CI}=[0.560,0.708]), \mathrm{KC}$ on KS at $(\beta=0.226, \mathrm{SE}=0.066 ; 95 \% \mathrm{CI}=[0.096,0.357]), \mathrm{KS}$ on KSI at $(\beta=0.115, \mathrm{SE}=0.037 ; 95 \% \mathrm{CI}=[0.043,0.186])$, OL on KSI at $(\beta=0.667, \mathrm{SE}=0.051 ; 95 \%$ $\mathrm{CI}=[0.566,0.768])$ and $\mathrm{KC}$ on OP at $(\beta=0.456, \mathrm{SE}=0.053 ; 95 \% \mathrm{CI}=[0.352,0.560])$. Although 

$(\beta=-0.027, \mathrm{SE}=0.038 ; 95 \% \mathrm{CI}=[-0.102,0.049]), \mathrm{OL}$ on $\mathrm{OP}$ at $(\beta=-0.035, \mathrm{SE}=0.063$; $95 \% \mathrm{CI}=[-0.159,0.090])$ were not significant, the effect of OL on OP before mediators inserting was significant at $(\beta=0.601, \mathrm{SE}=0.048 ; 95 \% \mathrm{CI}=[0.507,0.695])$. Thus, all direct hypotheses are accepted, except $\mathrm{H} 1 \mathrm{~b}$ and $\mathrm{H} 2 \mathrm{~b}$.

4.4.2 Indirect effect. As shown in Table 5, the indirect effect of $\mathrm{KC}$ at $(\beta=0.251, \mathrm{SE}=0.040$; $95 \% \mathrm{CI}=[0.461,0.650])$ and $\mathrm{KSI}$ at $(\beta=0.236, \mathrm{SE}=0.032 ; 95 \% \mathrm{CI}=[0.172,0.299])$ between $\mathrm{OL}$ and $\mathrm{OP}$ was significant. But, the indirect effect through KS was not significant at $(\beta=-0.007, \mathrm{SE}=0.010 ; 95 \% \mathrm{CI}=[-0.030,0.011])$. Consequently, H3a and H3c, were accepted, whereas $\mathrm{H} 3 \mathrm{~b}$ was rejected.

4.4.3 Serial/sequential mediation. In Table 5, the results present that the indirect effect of $\mathrm{OL}$ on $\mathrm{OP}$ through the serially mediating effect of $\mathrm{KC}, \mathrm{KS}$ and $\mathrm{KSI}$ at $(\beta=0.007$, s.e $=0.003$; $95 \% \mathrm{CI}=[0.002,0.015]$ ) was significant. It provides support for the serial mediation model. On the other hand, the indirect effect through $\mathrm{KC}$ and $\mathrm{KS}$ at $(\beta=-0.003, \mathrm{SE}=0.005 ; 95 \%$ $\mathrm{CI}=[-0.014,0.006]), \mathrm{KC}$ and KSI at $(\beta=0.010, \mathrm{SE}=0.013 ; 95 \% \mathrm{CI}=[-0.013,0.038])$ and $\mathrm{KS}$ and KSI at $(\beta=-0.012, \mathrm{SE}=0.005 ; 95 \% \mathrm{CI}=[-0.004,0.025])$ was insignificant. Therefore, $\mathrm{H} 4 \mathrm{~d}$ was accepted, whereas H4a, H4b and H4c were rejected.

\section{Discussion}

\subsection{Theoretical contribution}

This study extends KM research by investigating the serially mediating effect of KC, KS and KSI between OL-OP relationships. Previous studies have shown that companies face significant difficulties in learning from the crisis (Broekema et al., 2019). In this study, we examine the variables that lead OL out of crises (i.e. Covid-19). We applied "multiple regression analysis" through process macro to test the study's hypotheses. The study proposes that (1) OL and KM processes have the positive relationship with OP, (2) OL, KC and KS have the significant positive relationship with KSI and (3) KM processes serially mediate the relationship between $\mathrm{OL}$ and $\mathrm{OP}$. These theoretical predictions are supported by our empirical findings.

First, the results of hypothesis $\mathrm{H} 1 \mathrm{la}$ and $\mathrm{H} 2 \mathrm{a}$ show that OL has a positive effect on KSI and OP. Results are consistent with the past studies (Ricciardi et al., 2020; Noruzy et al., 2013). Second, the accepted hypotheses $\mathrm{H} 1 \mathrm{~b}, \mathrm{H} 2 \mathrm{c}$ and $\mathrm{H} 1$ cshow the significant positive effect of $\mathrm{KC}$ on OP, KS on KSI and KSI on OP in the software development industry of Pakistan. This result is linked to the findings that companies use information to create context, generate knowledge and make decisions in times of crisis (Sahibzada et al., 2020). The result of H3a and $\mathrm{H} 3 \mathrm{c}$ shows the significant indirect effect of $\mathrm{OL}$ on $\mathrm{OP}$ via $\mathrm{KC}$ and $\mathrm{KSI}$ respectively. Third, the result of $\mathrm{H} 4 \mathrm{~d}$ shows that the association between $\mathrm{OL}-\mathrm{OP}$ is sequentially mediated by $\mathrm{KC}, \mathrm{KS}$ and KSI. Findings are consistent with the earlier research, where indirect effects of OL on OP via KC, KS and KSI have been reported (Hutagalung et al., 2020; Kordab et al., 2020; Wahda, 2017).

\subsection{Practical implications}

The study has the following implications: First, by using the proposed framework, organizations can gauge their ability to learn from their experiences in a rapidly changing environment and to gain critical knowledge of how to better perform KM practices to strengthen $\mathrm{OP}$ during crises. Second, this study will provide new insights into the managers and policy makers, and how OL and KM work together to enhance OP during crisis. Third, the relationships between OL, KM and OP may provide a guideline as to how firms can enhance their performance by using OL to develop KM. Fourth, understanding the effect of 
OL and KM on OP would assist top-, middle- and first-line (lower) managers of the companies to identify their strategies in future development. The companies should be aware that OL and $\mathrm{KM}$ are crucial for success to operate in an environment of turbulence and uncertainty.
Knowledge management practices

\section{Conclusion}

Consistent with our expectations, the findings show that the link between OL-OP is mediated by KC, KS and KSI. This result reinforces the argument that OL and KM play a key role in improving the performance of organizations during the Covid-19 crisis. To tackle the coronavirus crisis, software development companies' managers should consider OL and KM practices significantly when focusing on efforts or planning to improve OP. In addition, for software companies it adds credence to the role played by KM in mediating the link between $\mathrm{OL}$ and $\mathrm{OP}$, which potentially enables managers to create and maintain a conducive learning environment. KM is vital because it increases the decision-making capacity of the company. All level managers within the companies should ensure that all technical and nontechnical workers have access to the overall skills available within the companies and a better workforce is developed that are more capable of making quick, informed decisions that benefit the company. During crises (e.g. Covid-19), there is a strong consensus that the core strategic advantage of an organization lies in its ability to learn and respond to challenges. Certainly, more attention needs to be paid to the development of OL to improve OP. This will only be possible when organizations create an environment where employees can learn and share information on a regular basis.

\section{Limitations and further research avenues}

Despite the promising findings, there are some limitations to this study, which provide opportunities for future research: First, the cultural differences in the companies or among managers that might influence the perceptions of learning and KM practices. In terms of generalizability and attain a broader view, it would be interesting to replicate the research by using the cross-culture samples. Second, this study adopts a cross-sectional approach, but a longitudinal research study would be more appropriate to establish the fundamental paths of the studied variables. Third, from a theoretical viewpoint, this study tests KM as a moderator between OL and OP. Future studies can test the mediating effect between transformational leadership and innovation performance. In addition, the future studies should consider the component variables of KC (i.e. externalization, socialization, combination, and internalization) for obtaining more comprehensive results.

\section{References}

Abusweilem, M. and Abualoush, S. (2019), "The impact of knowledge management process and business intelligence on organizational performance", Management Science Letters, Vol. 9 No. 12, pp. 2143-2156, doi: 10.5267/j.msl.2019.6.020.

Addis, M. (2016), "Tacit and explicit knowledge in construction management", Construction Management and Economics, Vol. 34 Nos 7-8, pp. 439-445, doi: 10.1080/01446193.2016.1180416.

Al-Emran, M., Mezhuyev, V., Kamaludin, A. and Shaalan, K. (2018), "The impact of knowledge management processes on information systems: a systematic review", International Journal of Information Management, Vol. 43, pp. 173-187, doi: 10.1016/j.ijinfomgt.2018.08.001.

Alles, M. (2021), "Using the creation of an XBRL risk taxonomy as a driver to improve postcoronavirus 10-K risk disclosures", Journal of Emerging Technologies in Accounting, Vol. 18 No. 1, pp. 175-183, doi: 10.2308/JETA-2020-057. 
Argote, L., McEvily, B. and Reagans, R. (2003), "Managing knowledge in organizations: an integrative framework and review of emerging themes", Management Science, Vol. 49 No. 4, pp. 571-582, doi: $10.1287 / \mathrm{mnsc}$.49.4.571.14424.

Argyris, C. (2000), Flawed Advice and the Management Trap: How Managers Can Know when They're Getting Good Advice and when They're Not, Oxford University Press, Oxford.

Argyris, C. and Schon, D.A. (1974), Theory in Practice: Increasing Professional Effectiveness, Josseybass Publishers, California.

Argyris, Smith, M. and Putnam (1985), Action Science: Concepts, Methods and Skills for Research and Intervention, Jossey-Bass Publishers, California.

Bagozzi, R.P., Yi, Y. and Nassen, K.D. (1998), "Representation of measurement error in marketing variables: review of approaches and extension to three-facet designs", Journal of Econometrics, Vol. 89 Nos 1-2, pp. 393-421, doi: 10.1016/S0304-4076(98)00068-2.

Benner, M. and Waldfogel, J. (2008), "Close to you? Bias and precision in patent-based measures of technological proximity”, Research Policy, Vol. 37 No. 9, pp. 1556-1567, doi: 10.1016/j.respol.2008. 05.011.

Bentler, P.M. and Bonett, D.G. (1980), "Significance tests and goodness of fit in the analysis of covariance structures”, Psychological Bulletin, Vol. 88 No. 3, pp. 588-606, doi: 10.1037/0033-2909. 88.3.588.

Boehm, J., Kaplan, J. and Sportsman, N. (2020), Cybersecurity's Dual Mission during the Coronavirus Crisis, Mckinsey Insights, available at: https://investinafrica.com/uploads/covid-resources/ MCKINSEY_AND_COMAPNY-CYBERSECURITY-DURING-CORONAVIRUS.pdf.

Boella, G., Di Caro, L., Humphreys, L., Robaldo, L., Rossi, P. and van der Torre, L. (2016), "Eunomos, a legal document and knowledge management system for the web to provide relevan, reliable and up-to-date information on the law", Artificial Intelligence and Law, Vol. 24 No. 3, pp. 245-283, doi: 10.1007/s10506-016-9184-3.

Broekema, W., Porth, J., Steen, T. and Torenvlied, R. (2019), "Public leaders' organizational learning orientations in the wake of a crisis and the role of public service motivation", Safety Science, Vol. 113, pp. 200-209, doi: 10.1016/j.ssci.2018.11.002.

Calabretta, G., Gemser, G. and Wijnberg, N.M. (2017), "The interplay between intuition and rationality in strategic decision making: a paradox perspective", Organization Studies, Vol. 38 Nos 3-4, pp. 365-401, doi: 10.1177/F0170840616655483.

Carmeli, A., Gelbard, R. and Reiter-Palmon, R. (2013), "Leadership, creative problem-solving capacity, and creative performance: the importance of knowledge sharing", Human Resource Management, Vol. 52 No. 1, pp. 95-121, doi: 10.1002/hrm.21514.

Carroll, J.S. and Hatakenaka, S. (2001), "Driving organizational change in the midst of crisis", MIT Sloan Management Review, Vol. 42 No. 3, pp. 70-79.

Cho, J.J.K., Ozment, J. and Sink, H. (2008), "Logistics capability, logistics outsourcing and firm performance in an e-commerce market", International Journal of Physical Distribution and Logistics Management, Vol. 38 No. 5, pp. 336-359, doi: 10.1108/09600030810882825.

Darroch, J. (2005), “Knowledge management, innovation and firm performance”, Journal of Knowledge Management, Vol. 9 No. 3, pp. 101-115, doi: 10.1108/13673270510602809.

Deverell, E. (2009), “Crises as learning triggers: exploring a conceptual framework of crisis-induced learning", Journal of Contingencies and Crisis Management, Vol. 17 No. 3, pp. 179-188, doi: 10. 1111/j.1468-5973.2009.00578.x.

Etikan, I., Musa, S.A. and Alkassim, R.S. (2016), “Comparison of convenience sampling and purposive sampling", American Journal of Theoretical and Applied Statistics, Vol. 5 No. 1, pp. 1-4, doi: 10. 11648/j.ajtas.20160501.11.

Fatima, T., Raja, U., Malik, M.A.R. and Jahanzeb, S. (2020), "Leader-member exchange quality and employees job outcomes: a parallel mediation model”, Eurasian Business Review, Vol. 10 No. 2, pp. 309-332, doi: 10.1007/s40821-020-00158-6. 
García-Morales, V.J., Matías-Reche, F. and Hurtado-Torres, N. (2008), "Influence of transformational leadership on organizational innovation and performance depending on the level of organizational learning in the pharmaceutical sector", Journal of Organizational Change Management, Vol. 21 No. 2, pp. 188-212, doi: 10.1108/09534810810856435.

Gefen, D., Straub, D. and Boudreau, M.-C. (2000), "Structural equation modeling and regression: guidelines for research practice", Communications of the Association for Information Systems, Vol. 4 No. 1, p. 7, doi: 10.17705/1CAIS.00407.

Gopalkrishna, B., Rodrigues, L.L., Poornima, P. and Manchanda, S. (2012), "Knowledge management in software companies - an appraisal", International Journal of Innovation, Management and Technology, Vol. 3 No. 5, pp. 608-613, available at: http://ijimt.org/papers/305-N20008.pdf.

Hansen, M.T., Nohria, N. and Tierney, T. (1999), "What's your strategy for managing knowledge”, The Knowledge Management Yearbook 2000-2001, Vol. 77 No. 2, pp. 106-116.

Hayes, J.R. (2013), The Complete Problem Solver, Routledge, New York.

Holtshouse, D. (1998), "Knowledge research issues", California Management Review, Vol. 40 No. 3, pp. 277-280, doi: 10.2307/F41165955.

Hu, L.-T. and Bentler, P.M. (1998), "Fit indices in covariance structure modeling: sensitivity to underparameterized model misspecification”, Psychological Methods, Vol. 3 No. 4, pp. 424-453, doi: 10.1037/1082-989X.3.4.424.

Hu, X., Yan, H., Casey, T. and Wu, C.-H. (2021), "Creating a safe haven during the crisis: how organizations can achieve deep compliance with COVID-19 safety measures in the hospitality industry", International Journal of Hospitality Management, Vol. 92, 102662, doi: 10.1016/j.ijhm. 2020.102662.

Hutagalung, D., Sopa, A., Asbari, M., Cahyono, Y., Maesaroh, S., Chidir, G. and Winanti, D.S. (2020), "Influence soft skills, hard skills and organization learning on teachers performance through inovation capability as mediator", Journal of Critical Reviews, Vol. 7 No. 19, pp. 54-66, available at: http://www.jcreview.com/fulltext/197-1594812713.pdf.

Jöreskog, K.G. and Sörbom, D. (1993), LISREL 8: Structural Equation Modeling with the SIMPLIS Command Language, Scientific Software International, Chicago.

Kao, S.-C. and Wu, C. (2016), "The role of creation mode and social networking mode in knowledge creation performance: mediation effect of creation process", Information and Management, Vol. 53 No. 6, pp. 803-816, doi: 10.1016/j.im.2016.03.002.

Khosravi, A. and Nilashi, M. (2018), "Toward software quality enhancement by customer knowledge management in software companies", Telematics and Informatics, Vol. 35 No. 1, pp. 18-37, doi: 10.1016/j.tele.2017.09.007.

Kordab, M., Raudeliūnienè, J. and Meidute-Kavaliauskienè, I. (2020), "Mediating role of knowledge management in the relationship between organizational learning and sustainable organizational performance", Sustainability, Vol. 12 No. 23, 10061, doi: 10.3390/su122310061.

Kuo, R.Z. and Lee, G.G. (2011), "Knowledge management system adoption: exploring the effects of empowering leadership, task-technology fit and compatibility", Behaviour and Information Technology, Vol. 30 No. 1, pp. 113-129, doi: 10.1080/0144929X.2010.516018.

Lee, C.S. and Wong, K.Y. (2015), "Development and validation of knowledge management performance measurement constructs for small and medium enterprises", Journal of Knowledge Management, Vol. 19 No. 4, pp. 711-734, doi: 10.1108/JKM-10-2014-0398.

Lyles, M.A. (2014), "Organizational learning, knowledge creation, problem formulation and innovation in messy problems", European Management Journal, Vol. 32 No. 1, pp. 132-136, doi: 10.1016/j. emj.2013.05.003.

Mehralian, G., Nazari, J.A. and Ghasemzadeh, P. (2018), "The effects of knowledge creation process on organizational performance using the BSC approach: the mediating role of intellectual capital", Journal of Knowledge Management, Vol. 22 No. 4, pp. 802-823, doi: 10.1108/JKM-10-2016-0457.
Knowledge management practices

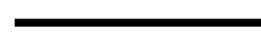


Nguyen-Duc, A., Cruzes, D.S. and Conradi, R. (2015), "The impact of global dispersion on coordination, team performance and software quality - a systematic literature review", Information and Software Technology, Vol. 57, pp. 277-294, doi: 10.1016/j.infsof.2014.06.002.

Nonaka, I. and Takeuchi, H. (1995), The Knowledge-Creating Company: How Japanese Companies Create the Dynamics of Innovation, Oxford University Press, New York, NY.

Noruzy, A., Dalfard, V.M., Azhdari, B., Nazari-Shirkouhi, S. and Rezazadeh, A. (2013), "Relations between transformational leadership, organizational learning, knowledge management, organizational innovation, and organizational performance: an empirical investigation of manufacturing firms", The International Journal of Advanced Manufacturing Technology, Vol. 64 Nos 5-8, pp. 1073-1085, doi: 10.1007/s00170-012-4038-y.

Nunnally, J.C. (1978), Psychometric Theory, 2nd ed., McGraw-Hill, New York, NY.

Obeidat, B.Y. and Zyod, D.S. (2015), "The associations among transformational leadership, transactional leadership, knowledge sharing, job performance, and firm performance: a theoretical model”, Journal of Social Sciences (COES and RJ-JSS), Vol. 4 No. 2, pp. 848-866, doi: 10.25255/jss.2015.4.2.848.866.

Obeso, M., Hernández-Linares, R., López-Fernández, M.C. and Serrano-Bedia, A.M. (2020), "Knowledge management processes and organizational performance: the mediating role of organizational learning", Journal of Knowledge Management, Vol. 24 No. 8, pp. 1859-1880, doi: 10.1108/JKM-102019-0553.

Ode, E. and Ayavoo, R. (2020), "The mediating role of knowledge application in the relationship between knowledge management practices and firm innovation", Journal of Innovation and Knowledge, Vol. 5 No. 3, pp. 210-218, doi: 10.1016/j.jik.2019.08.002.

Oliveira, M., Curado, C., Balle, A.R. and Kianto, A. (2020), "Knowledge sharing, intellectual capital and organizational results in SMES: are they related?", Journal of Intellectual Capital, Vol. 21 No. 6, pp. 893-911, doi: 10.1108/JIC-04-2019-0077.

Olsson, E.K. (2014), "Crisis communication in public organisations: dimensions of crisis communication revisited", Journal of Contingencies and Crisis Management, Vol. 22 No. 2, pp. 113-125.

Park, S. and Kim, E.-J. (2018), "Fostering organizational learning through leadership and knowledge sharing", Journal of Knowledge Management, Vol. 22 No. 6, pp. 1408-1423, doi: 10.1108/JKM-102017-0467.

Pasamar, S., Diaz-Fernandez, M. and de la Rosa-Navarro, M.D. (2019), "Human capital: the link between leadership and organizational learning", European Journal of Management and Business Economics, Vol. 28 No. 1, pp. 25-51, doi: 10.1108/EJMBE-08-2017-0003.

Popper, M. and Lipshitz, R. (1998), "Organizational learning mechanisms: a structural and cultural approach to organizational learning", The Journal of Applied Behavioral Science, Vol. 34 No. 2, pp. 161-179, doi: 10.1177/2F0021886398342003.

Putra, R. and Ruslan, S. (2021), "Influence work discipline, organizational learning, and motivation to employee performance at PT CIMB Niaga Tbk", Dinasti International Journal of Digital Business Management, Vol. 2 No. 2, pp. 324-334, doi: 10.31933/dijdbm.v2i2.775.

Qadri, U.A., Ghani, M.B.A. and Sheikh, M.A. (2020), "Role of corporate identity, image and reputation in investors' behavioral decision making: does emotional attachment matter?”, Pakistan Journal of Commerce and Social Sciences (PJCSS), Vol. 14 No. 1, pp. 120-142.

Ricciardi, F., De Bernardi, P. and Cantino, V. (2020), "System dynamics modeling as a circular process: the smart commons approach to impact management", Technological Forecasting and Social Change, Vol. 151, 119799, doi: 10.1016/j.techfore.2019.119799.

Saha, D. and Annamalai, M. (2021), "Machine learning techniques for analysis of hyperspectral images to determine quality of food products: a review", Current Research in Food Science, Vol. 4, pp. 28-44, doi: 10.1016/j.crfs.2021.01.00. 
Sahibzada, U.F., Jianfeng, C., Latif, K.F., Shah, S.A. and Sahibzada, H.F. (2020), "Refuelling knowledge management processes towards organisational performance: mediating role of creative organisational learning", Knowledge Management Research and Practice, pp. 1-13, doi: 10. 1080/14778238.2020.1787802.

Sawaean, F. and Ali, K. (2020), "The impact of entrepreneurial leadership and learning orientation on organizational performance of SMEs: the mediating role of innovation capacity", Management Science Letters, Vol. 10 No. 2, pp. 369-380, doi: 10.5267/j.msl.2019.8.033.

Senge, P.M. (1990), The Fifth Discipline. The Art and Practice of the Learning Organization, Bantam Doubleday Dell Publishing Group, New York, NY.

Singh, S.K., Chen, J., Del Giudice, M. and El-Kassar, A.-N. (2019), "Environmental ethics, environmental performance, and competitive advantage: role of environmental training", Technological Forecasting and Social Change, Vol. 146 No. C, pp. 203-211, doi: 10.1016/j.techfore.2019.05.032.

Truong, Y. and McColl, R. (2011), "Intrinsic motivations, self-esteem, and luxury goods consumption", Journal of Retailing and Consumer Services, Vol. 18 No. 6, pp. 555-561.

Tseng, S.M. and Lee, P.S. (2014), "The effect of knowledge management capability and dynamic capability on organizational performance", Journal of Enterprise Information Management, Vol. 27 No. 2, pp. 158-179, doi: 10.1108/JEIM-05-2012-0025.

Ullah, Y., Ullah, H. and Jan, S. (2021), "The mediating role of employee creativity between knowledge sharing and innovative performance: empirical evidence from manufacturing firms in emerging markets", Management Research Review. doi: 10.1108/MRR-03-2020-0164.

Velásquez, R.M.A. and Lara, J.V.M. (2021), "Knowledge management in two universities before and during the COVID-19 effect in Peru”, Technology in Society, Vol. 64 No. 7, 101479, doi: 10.1016/j. techsoc.2020.101479.

Wahda, W. (2017), "Mediating effect of knowledge management on organizational learning culture toward organization performance", Journal of Management Development, Vol. 36 No. 7, pp. 846-858.

Waheed, S., Hamid, B., Jhanjhi, N., Humayun, M. and Malik, N.A. (2019), "Improving knowledge sharing in distributed software development", International Journal of Advanced Computer Science and Applications (IJACSA), Vol. 10 No. 6, pp. 434-443, available at: https://expert.taylors. edu.my/file/rems/publication/109566_6019_1.pdf.

Zaim, H., Muhammed, S. and Tarim, M. (2019), "Relationship between knowledge management processes and performance: critical role of knowledge utilization in organizations", Knowledge Management Research and Practice, Vol. 17 No. 1, pp. 24-38, doi: 10.1080/14778238.2018. 1538669.

Zhang, H., Gupta, S., Sun, W. and Zou, Y. (2020), "How social-media-enabled co-creation between customers and the firm drives business value? The perspective of organizational learning and social capital", Information and Management, Vol. 57 No. 3, pp. 1-27, doi: 10.1016/j.im.2019. 103200.

\section{Appendix}

Measures and items

A. Organizational learning (García-Morales et al., 2008)

(Five-point Likert scale, in which $1=$ strongly disagree $-5=$ strongly agree, four-item construct)

(1) During crisis, the organization has acquired and used much new and relevant knowledge that has provided competitive advantage.

(2) The organization's members have acquired critical capacities and skills that have provided competitive advantage during crisis.

(3) Organizational improvements have been influenced fundamentally by new knowledge entering the organization.

(4) Our organization is a learning organization. 


\section{a. Knowledge creation (Lee and Wong, 2015)}

(1) In the time of crisis, employees work in teams to create new knowledge.

(2) In the time of crisis, employees participate in brainstorming sessions to create new knowledge.

(3) New knowledge, ideas and solutions created in the time of crisis.

(4) Our organization giving reward to employees who create new knowledge, ideas and solutions.

(5) Our company culture welcomes debates and stimulates discussions (Popper and Lipshitz, 1998).

\section{b. Knowledge storage}

(1) We have systems to capture and store ideas and knowledge during a crisis (Hansen et al., 1999).

(2) We have systems to codify and categorize ideas in a format that is easier to save for future use (Hansen et al., 1999).

(3) In the times of crisis, IT facilitates the processes of capturing, categorizing, storing, and retrieving knowledge and ideas in our company (Hansen et al., 1999).

c. Knowledge sharing (Lee and Wong, 2015)

(1) In the time of crisis, employees participate in informal discussion to share knowledge.

(2) Organization arranges frequency meeting sessions during a crisis.

(3) During crisis, employees using technological tools (e-mail, etc.) to transfer knowledge.

(4) For sharing the knowledge mostly time organization create the paired of mentors-mentees.

(5) Employees' frequency interactive with each other during a crisis.

(6) We have systems and venues for people to share knowledge and learn from each other in the company (Holtshouse, 1998).

\section{Organizational performance (Cho et al., 2008)}

(Five-point scale, in which $5=$ excellent $-1=$ poor; four items were retained for this construct)

Relative to your businesses' largest competitors in the software development industry, how well does your company perform in the following areas?

(1) Profitability;

(2) Sales growth;

(3) Customer satisfaction and

(4) Overall performance

\section{Corresponding author}

Usman Ahmad Qadri can be contacted at: usmanahmadqadri@hotmail.com

For instructions on how to order reprints of this article, please visit our website:

www.emeraldgrouppublishing.com/licensing/reprints.htm

Or contact us for further details: permissions@emeraldinsight.com 